\title{
IDENTIFIKASI DAN DERAJAT INFESTASI Lernaea PADA IKAN MASKOKI (Carassius auratus) DI KABUPATEN TULUNGAGUNG, JAWA TIMUR
}

\author{
Identification and Degrees of Lernaea Infestation in Goldfish (Carassius Auratus) at \\ Tulungagung, East Java
}

\author{
Bernideta Dewi Kriswijayanti ${ }^{1}$, Kismiyati ${ }^{2}$, dan Kusnoto ${ }^{3}$ \\ ${ }^{1}$ Program Studi Budidaya Perairan, Fakultas Perikanan dan Kelautan, Universitas Airlangga, Surabaya \\ ${ }^{2}$ Departemen Manajemen Kesehatan Ikan dan Budidaya Perairan, Fakultas Perikanan dan Kelautan, Universitas \\ Airlangga, Surabaya \\ ${ }^{3}$ Departemen Parasitologi Veteriner, Fakultas Kedokteran Hewan, Universitas Airlangga, Surabaya \\ *bernideta@fpk.unair.ac.id
}

\begin{abstract}
Abstrak
Penyakit merupakan masalah yang penting yang harus diperhatikan oleh pembudidaya ikan agar tidak mengalami kerugian. Penyakit dapat muncul di suatu perairan akibat ketidakseimbangan antara lingkungan, inang, dan patogen. Salah satu penyakit yang sering menyerang ikan hias air tawar adalah lernaeosis. Lernaeosis adalah penyakit pada ikan yang disebabkan oleh serangan ektoparasit copepoda dari genus Lernaea. Ektoparasit ini dapat ditemukan pada seluruh permukaan tubuh, mulut dan insang ikan. Lernaea dapat menyebabkan iritasi pada kulit serta lesi. Ikan maskoki (Carrassius auratus) merupakan salah satu jenis ikan hias air tawar tergolong dalam jenis ikan karper yang sering terserang Lernaea. Ikan maskoki (Carassius auratus) merupakan komoditas unggulan perikanan budidaya untuk jenis ikan hias air tawar di Tulungagung. Identifikasi dan derajat infestasi Lernaea yang menyerang ikan maskoki (Carassius auratus) di Tulungagung, Jawa Timur belum banyak diteliti sehingga perlu dilakukan penelitian pada tiga desa yaitu Desa Karang Rejo, Desa Ploso Kandang dan Desa Wajak dimana ketiga desa tersebut merupakan sentra budidaya di Kabupaten Tulungagung. Tujuan penelitian ini adalah untuk mengetahui spesies Lernaea yang menyerang ikan maskoki (Carassius auratus) dan derajat infestasi dari serangan Lernaea pada ikan maskoki yang dibudidayakan di tiga desa yang berada di Desa Karang Rejo, Desa Ploso Kandang dan Desa Wajak, Kabupaten Tulungagung, Jawa Timur. Identifikasi Lernaea dilakukan di Laboratorium Fakultas Perikanan dan Kelautan Universitas Airlangga Surabaya dan penggambaran spesimen dilakukan di LIPI Cibinong. Data hasil identifikasi spesies Lernaea yang menyerang ikan maskoki disajikan secara deskriptif dalam bentuk gambar untuk identifikasi Lernaea dan dalam bentuk tabel untuk derajat infestasi. Hasil penelitian yang dilakukan di Desa Karang Rejo, Desa Ploso Kandang dan Desa Wajak hanya ditemukan satu spesies saja, yaitu Lernaea cyprinacea. Derajat infestasi dari serangan Lernaea cyprinacea di tiga desa tersebut tergolong dalam infestasi ringan.
\end{abstract}

Kata kunci: Lernaea cyprinacea, ikan maskoki, derajat infestasi, identifikasi, Tulungagung

Abstract

Disease is important problem in aquaculture to prevent disadvantages. Disease in aquaculture caused state of inbalance between environtment, host and pathogen. One of disease than often attacked on freshwater fish is lernaeosis. Lernaeosis is disease in fish caused by ectoparasites like copepoda from genus Lernaea. This ectoparasite can found in through all in surface body, mouth and gill. Lernea caused irritation in skin with lesion. Goldfish (Carassius auratus) is one of ornamental freshwater carper that often attacked by Lernaea. Goldfish (Carassius auratus) is priority comodity fisheries culture for kind ornamental freshwater fish in Tulungagung. Identification and degrees of infestation Lernaea that attacked Goldfish (Carassius auratus) in Tulungagung, East Java haven't been know in Karang Rejo, Ploso Kandang, and Wajak that three villages sentralized of aquaculture in Tulungangung. The purpose of this research was know that Lernaea which are attacked goldfish (Carassius auratus) and degrees of infestation Lernaea in goldfish which culture in Karang Rejo, Ploso Kandang, and Wajak, Tulungagung, East Java. Identification of Lernea was conducted at Laboratory of Faculty of Fisheries and Marine Universitas Airlangga Surabaya and drawing the speciments were conducted at LIPI Cibinong. Data of identification species of Lernaea that attacked goldfish attacked fish shown by descriptive in pictures and table for degrees of Infestation. Result of research in Karang Rejo, Ploso Kandang, and Wajak only found one species is Lernaea cyprinacea. Degrees of infestation Lernaea cyprinacea in three village categorization in low infestation. 


\section{PENDAHULUAN}

Keberadaan penyakit dalam budidaya ikan merupakan masalah yang serius yang dihadapi para pembudidaya. Penyakit merupakan masalah yang penting yang harus diperhatikan oleh pembudidaya ikan agar tidak mengalami kerugian. Penyakit dapat muncul di suatu perairan akibat ketidakseimbangan antara lingkungan, inang, dan patogen. Penanganan dalam budidaya yang kurang baik dapat menyebabkan ikan mengalami stres, sehingga daya tahan tubuh menurun dan mudah terserang penyakit (Syawal dkk., 2008).

Penyakit yang sering menyerang ikan hias air tawar salah satunya berasal dari serangan parasit. Parasit merupakan organisme yang menempel pada inang dan menyerap makanan dari inang tersebut (Rukyani dan Komarudin, 1991). Parasit juga dapat mengakibatkan penurunan kualitas dan kuantitas ikan budidaya, pertumbuhan ikan terhambat bahkan dapat terjadi kematian, sehingga menyebabkan penurunan produksi dan kualitas ikan hias (Alifuddin dkk., 2002).

Lernaeosis adalah penyakit pada ikan yang disebabkan oleh serangan ektoparasit Copepoda dari genus Lernaea. Ektoparasit ini dapat ditemukan pada seluruh permukaan tubuh, mulut, sirip dan insang ikan. Lernaea dapat menyebabkan iritasi pada kulit serta lesi. Lernaea dalam budidaya selalu berhubungan dengan mortalitas yang tinggi (Kismiyati dkk., 2011) dan akibat yang ditimbulkan bagi pembudidaya adalah kerugian yang besar apabila ikan yang dibudidaya mengalami kematian dalam jumlah yang besar. Kejadian lernaeosis pada kolam budidaya di Indonesia perlu mendapatkan perhatian, karena kejadian lernaeosis sering menyerang ikan budidaya (Karantina Ikan Ngurah Rai, 2004).

Ikan maskoki (Carrassius auratus) merupakan salah satu jenis ikan hias air tawar tergolong dalam jenis ikan karper yang sering terserang Lernaea. Ikan maskoki (Carassius auratus) merupakan komoditas unggulan perikanan budidaya untuk jenis ikan hias air tawar di Tulungagung (Direktorat Jenderal Perikanan Budidaya, 2012). Hal tersebut mengakibatkan para pembudidaya mengalami kerugian akibat dari serangan Lernaea. Identifikasi dan derajat infestasi Lernaea yang menginfestasi ikan maskoki (Carassius auratus) di Kabupaten Tulungagung, Jawa Timur belum banyak diteliti sehingga data dan informasi yang didapat masih kurang.

\section{METODOLOGI \\ Waktu dan Tempat}

Penelitian dilaksanakan di Desa

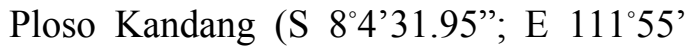
32.22”), Desa Wajak (S 8 $6^{\circ} 35.37^{\prime \prime} ;$ E $111^{\circ}$ 54'56.52"), Desa Karang Rejo (S 8 $0^{\prime}$ 23.60”; E 111'54'31.66”) Kabupaten Tulungagung, dan Laboratorium Pendidikan Fakultas Perikanan dan Kelautan Universitas Airlangga, Surabaya bulan Maret Agustus 2013.

\section{Metode Penelitian}

Pengambilan Sampel

Sampel ikan maskoki diambil dari tiga desa yang berada di Kabupaten Tulungagung, Jawa Timur dengan dua kolam untuk masing-masing desa. Kolam budidaya berupa kolam beton yang berukuran $4 \mathrm{~m} \times 2 \mathrm{~m} \times 60 \mathrm{~cm}$ dengan populasi ikan tiap kolam pada setiap desa berbeda. Desa Karang Rejo dan Desa Ploso Kandang memilki populasi sebanyak 200 ekor untuk setiap kolam, sedangkan untuk Desa Wajak memiliki populasi sebanyak 150 ekor untuk setiap kolam. Pengambilan sampel dilakukan sebanyak $10 \%$ dari populasi.

Pengambilan jumlah sampel ini sesuai dengan pernyataan Gay dan Diehl (1992) bahwa untuk penelitian deskriptif, sampel yang diperlukan adalah $10 \%$ dari populasi. Pada penelitian ini diambil 20 ekor ikan untuk tiap kolam di Desa Karang Rejo dan Ploso Kandang, sedangkan untuk

Diterima/submitted:4 November 2013 Disetujui/accepted:24 Desember 2013 
Desa Wajak diambil 15 ekor ikan untuk tiap kolam yang memiliki panjang 7,5-16,5 cm sehingga diperoleh 110 ekor ikan. Sampel dimasukkan ke dalam kantong plastik dan diberi oksigen lalu dibawa ke Laboratorium Pendidikan Fakultas Perikanan dan Kelautan Universitas Airlangga, Surabaya. Pengukuran kualitas air dilakukan langsung di lokasi pengambilan sampel pada saat pengambilan sampel berlangsung.

\section{Penentuan Derajat Infestasi}

Sampel ikan maskoki yang telah didapat dari Desa Ploso Kandang, Desa Wajak dan Desa Karang Rejo, Kabupaten Tulungagung dipisahkan antara sampel ikan yang positif dan yang negatif terinfestasi Lernaea. Sampel ikan yang positif terinfestasi Lernaea kemudian dihitung jumlah Lernaea pada tiap ekor ikan untuk menentukan derajat infestasi dari tiap sampel, setelah itu dilakukan pengelompokan sesuai derajat infestasi dari tiap ekor sampel ikan yang terinfestasi Lernaea.

Menurut Kismiyati (2009), penentuan derajat infestasi pada ektoparasit yaitu derajat infestasi ringan bila ditemukan 1-5 parasit, dikatakan derajat infestasi sedang apabila ditemukan 6-10 parasit dan disebut derajat infestasi berat bila ditemukan lebih dari 10 parasit. Ikan dapat dikatakan normal dan sehat apabila tidak terinfestasi Lernaea.

\section{Identifikasi Lernaea}

Identifikasi Lernaea dilakukan setelah penentuan dan pengelompokan derajat infestasi. Parasit Lernaea diambil dari sampel ikan maskoki yang terinfestasi Lernaea dengan menggunakan pinset, kemudian diawetkan dengan menggunakan alkohol gliserin 5\% dan disimpan dalam pot sampel untuk di identifikasi. Lernaea yang sudah disimpan didalam pot sampel kemudian dilakukan pewarnaan dan pembuatan slide preparat dimana pewarnaan Lernaea dengan menggunakan metode Semichen-Acetic Carmine yang mengacu pada (Fidyandini dkk., 2012).
Setelah itu dilakukan pengamatan dengan menggunakan mikroskop di Laboratorium Pendidikan Fakultas Perikanan dan Kelautan Universitas Airlangga, Surabaya.

Pengamatan dilakukan di bawah mikroskop dengan perbesaran 40x dan 100x yang dilakukan di Laboratorium Pendidikan Fakultas Perikanan dan Kelautan Universitas Airlangga dan kemudian dilakukan penggambaran spesimen Lernaea dengan menggunakan kamera Lucida dengan perbesaran 40x dan 100x di LIPI Cibinong. Identifikasi Lernaea ini dilakukan sesuai kunci identifikasi menurut Kabata (1979).

\section{HASIL DAN PEMBAHASAN \\ Identifikasi Lernaea pada ikan maskoki}

Hasil identifikasi Lernaea yang menginfestasi ikan maskoki di Desa Ploso Kandang, Desa Wajak, Desa Karang Rejo di Kabupaten Tulungagung, Jawa Timur hanya ditemukan satu spesies yaitu Lernaea cyprinacea. Lernaea cyprinacea memiliki panjang total 5-9 $\mathrm{mm}$. Bagian cephalotorax memiliki empat cabang yang disebut holdfast dan holdfast tersebut terbagi menjadi dua bagian yaitu bagian dorsal dan ventral. Pada bagian dorsal berukuran lebih besar dibandingkan bagian ventral. Bagian dorsal dibagi menjadi dua cabang (membentuk huruf $\mathrm{T}$ ) sedangkan pada bagian ventral tidak memiliki cabang. Lernaea cyprinacea memiliki tiga pasang kaki renang diantara cephalotorax dan lubang genital dimana setiap kaki terdiri dari tiga ruas. Bagian posterior Lernaea cyprinacea betina terdapat kantung telur yang memilki panjang $0,5-2 \mathrm{~mm}$. Pada bagian posterior juga terdapat uropod berbentuk silindris yang memiliki dua setae. Hasil pengamatan ini sesuai dengan kunci identifikasi dari Kabata (1979).

Diterima/submitted:4 November 2013 Disetujui/accepted:24 Desember 2013 


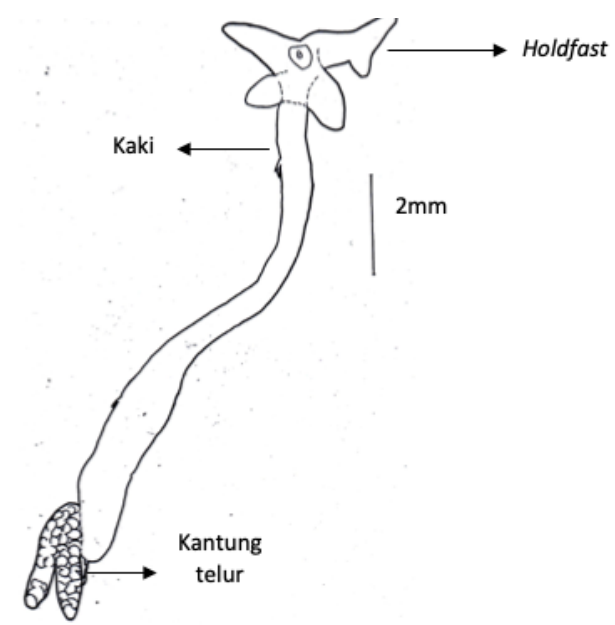

Gambar 1. Identifikasi Lernaea

\section{Derajat infestasi Lernaea pada ikan maskoki}

Jumlah sampel ikan maskoki yang digunakan, dari 110 sampel ikan dari tiga desa sebanyak 47 ekor ikan maskoki yang positif terinfestasi Lernaea cyprinacea, kemudian dikelompokkan dalam derajat infestasi ringan, infestasi sedang dan infestasi berat. Hasil dari pengelompokan menunjukkan bahwa $100 \%$ terinfestasi ringan. Pada tingkat infestasi ringan ditemukan 1-5 Lernaea cyprinacea pada setiap ekor ikan (Kismiyati, 2009). Jumlah ikan maskoki yang terinfestasi Lernaea cyprinacea dari tiga desa dapat dilihat pada Tabel 1.

Tabel 1. Derajat Infestasi Ikan yang Terinfestasi Lernaea cyprinacea di Desa Ploso Kandang, Desa Wajak dan Desa Karang Rejo, Kabupaten Tulungagung, Jawa Timur

\begin{tabular}{lllll}
\hline \multirow{2}{*}{ Desa } & Jumlah & sampel & \multicolumn{2}{l}{ Derajat Infestasi } \\
& (ekor) & Ringan (ekor) & Sedang (ekor) & Berat (ekor) \\
\hline Karang Rejo & 40 & 40 & 0 & 0 \\
Ploso Kandang & 40 & 40 & 0 & 0 \\
Wajak & 30 & 30 & 0 & 0 \\
\hline
\end{tabular}

Pengukuran kualitas air dilakukan pada parameter suhu, DO dan amoniak. Hasil pengukuran kualitas air pada masingmasing desa adalah untuk suhu kolam Desa Karang Rejo berkisar antara $28-30^{\circ} \mathrm{C}$, DO pada kolam $6 \mathrm{mg} / \mathrm{l}$ serta amoniak dalam kolam 0,5 mg/l. kondisi suhu, sedangkan untuk Desa Ploso Kandang suhu kolam berkisar $28-29^{\circ} \mathrm{C}$, DO pada kolam $6 \mathrm{mg} / 1$ serta amoniak pada kolam $0,5 \mathrm{mg} / \mathrm{l}$, dan untuk Desa Wajak suhu kolam berkisar 30$31^{\circ} \mathrm{C}$, DO pada kolam berkisar antara 6-8 $\mathrm{mg} / \mathrm{l}$ serta amoniak pada kolam $0 \mathrm{mg} / \mathrm{l}$.

Hasil identifikasi Lernaea yang menyerang ikan maskoki di Desa Ploso Kandang, Desa Wajak dan Desa Karang Rejo, Kabupaten Tulungagung hanya ditemukan satu spesies saja, yaitu Lernaea cyprinacea, hal ini karena inang dari Lernaea cyprinacea adalah ikan dari Familia Cyprinidae, termasuk ikan maskoki (Marina et al., 2008). Penyebaran Lernaea cyprinacea sangat luas, hal ini sesuai dengan pernyataan Shariff and
Sommerville (1986) bahwa penyebaran Lernaea cyprinacea antara lain di Eropa, Afrika, India, Asia tenggara, Asia timur, Amerika utara dan selatan.

Menurut Kabata (1985), Lernaea cyprinacea adalah spesies yang sering ditemukan di Asia Tenggara yang memiliki iklim tropis. Indonesia merupakan salah satu negara yang beriklim tropis sehingga sering sekali ditemukan infestasi Lernaea cyprinacea pada ikan air tawar. Ditemukannya Lernaea cyprinacea di Indonesia ini berawal dari masuknya ikan maskoki melalui jalur perdagangan, sehingga ketika ikan maskoki tersebut terinfetasi Lernaea cyprinacea dan dipasarkan di Indonesia maka parasit tersebut juga tersebar di Indonesia.

Lernaea cyprinacea yang ditemukan pada penelitian ini dilakukan pengamatan pada bagian holdfast yang merupakan kunci untuk mengidentifikasi spesies Lernaea. Bagian holdfast pada Lernaea cyprinacea ini memiliki empat cabang yang

Diterima/submitted:4 November 2013 Disetujui/accepted:24 Desember 2013 
terbagi menjadi dua bagian yaitu bagian dorsal dan ventral. Pada bagian dorsal berukuran lebih besar dibandingkan bagian ventral. Bagian dorsal dibagi menjadi dua cabang (membentuk huruf T) sedangkan pada bagian ventral tidak memiliki cabang.

Hasil pengamatan pada penelitian ini menunjukkan bahwa Lernaea cyprinacea menginfestasi ikan maskoki pada bagian sirip, mata dan tubuh. Pengamatan infestasi Lernaea cyprinacea pada ikan maskoki dilakukan di masingmasing desa yaitu Desa Ploso Kandang, Desa Wajak dan Desa Karang Rejo, Kabupaten Tulungagung. Sebanyak 110 ekor ikan maskoki, 47 ekor ikan maskoki positif terinfestasi Lernaea cyprinacea sedangkan 63 ekor negatif terinfestasi Lernaea cyprinacea. Ikan maskoki yang terinfestasi Lernaea cyprinacea tersebut kemudian dihitung jumlah Lernaea cyprinacea pada setiap ekor ikan maskoki. Pada Desa Karang Rejo ditemukan 1-5 Lernaea cyprinacea pada setiap ekor ikan maskoki, untuk Desa Ploso Kandang ditemukan 1-3 Lernaea cyprinacea pada setiap ekor ikan maskoki, sedangkan untuk Desa Wajak ditemukan 1-4 Lernaea cyprinacea pada setiap ekor ikan maskoki.

Hasil perhitungan jumlah Lernaea cyprinacea pada setiap ekor ikan tersebut kemudian dikelompokkan dalam derajat infestasi ringan, infestasi sedang dan infestasi berat. Sampel ikan maskoki dari tiga desa tersebut yang positif terinfestasi Lernaea cyprinacea tergolong dalam infestasi ringan karena hanya ditemukan 15 Lernaea cyprinacea pada setiap ekor ikan di tiga desa yang menjadi sentra budidaya ikan maskoki di Kabupaten Tulungagung Jawa Timur. Infestasi ringan terjadi diduga karena pada saat pengambilan sampel Lernaea cyprinacea masih dalam tahap copepodid atau tahap lain yang belum menginfestasi tubuh inang atau dapat juga telah mengalami kematian dan lepas dari tubuh inang, sehingga hanya sedikit yang ditemukan pada inang.

Pada tahap copepodid, Lernaea cyprinacea belum menetap pada inang sedangkan pada tahap cyclopoid, Lernaea cyprinacea sudah menjadi parasit yang menginfestasi inang dan berkembang sampai dewasa (Steckler and Yanong, 2012). Lernaea cyprinacea yang ditemukan dalam penelitian ini sebagian besar memiliki kantung telur, hal ini sesuai dengan pernyataan Shariff and Sommerville (1986) bahwa Lernaea cyprinacea dewasa yang menginfestasi tubuh inang adalah indvidu betina yang kemudian berkembang dan menghasilkan telur pada kantung telur, sedangkan individu jantan mati ketika 24 jam setelah tahap cyclopoid.

Pengukuran kualitas air dilakukan pada parameter suhu, DO dan amoniak. Hasil pengukuran kualitas air menunjukkan suhu pada tiga desa berkisar antara 28$31{ }^{\circ} \mathrm{C}$, DO pada kolam berkisar antara 6-8 $\mathrm{mg} / \mathrm{l}$, amoniak dalam kolam berkisar antara $0-0,5 \mathrm{mg} / 1$ serta $\mathrm{pH}$ air 7. Ditemukannya Lernaea cyprinacea pada penelitian ini karena Lernaea cyprinacea dapat hidup pada suhu $24-29^{\circ} \mathrm{C}$ dan $\mathrm{pH}$ air antara 5,6 9 (Shariff and Sommerville, 1986) dimana rentang suhu dan $\mathrm{pH}$ air tersebut sesuai dengan lokasi penelitian. Lernaea cyprinacea dapat ditemukan pada perairan hangat dengan suhu antara $20-30^{\circ} \mathrm{C}$ dan pada suhu tersebut Lernaea cyprinacea dapat berkembang (Kanwal et al., 2012). Sumber air dari kolam budidaya tersebut berasal dari sungai disekitar desa tersebut.

Hasil dari pengukuran kualitas air kolam budidaya tempat pengambilan sampel menunjukkan bahwa kualitas air dalam kolam budidaya tersebut masih dalam kondisi normal dan dapat ditoleransi oleh ikan maskoki. Kondisi ini dapat menyebabkan pertumbuhan Lernaea cyprinacea berlangsung dalam waktu yang lebih lama, sehingga pada ikan maskoki masih ditemukan adanya infestasi Lernaea cyprinacea dalam jumlah yang sedikit dan tergolong dalam infestasi ringan. Penyakit dapat muncul di suatu perairan akibat ketidakseimbangan antara lingkungan, ikan, dan patogen. Penanganan dalam budidaya yang kurang baik dapat

Diterima/submitted:4 November 2013 Disetujui/accepted:24 Desember 2013 
menyebabkan ikan mengalami stres, sehingga daya tahan tubuhnya menurun dan mudah terserang penyakit (Syawal dkk., 2008).

\section{KESIMPULAN DAN SARAN Kesimpulan}

Dari hasil penelitian ini dapat disimpulkan Lernaea yang menyerang ikan maskoki di Desa Karang Rejo, Desa Ploso Kandang dan Desa Wajak, Tulungagung Jawa Timur adalah Lernaea cyprinacea. Derajat infestasi Lernaea cyprinacea pada ikan maskoki di tiga desa di Kabupaten Tulungagung termasuk dalam kategori infestasi ringan.

\section{Saran}

Saran dari hasil penelitian ini adalah sebaiknya para pembudidaya ikan maskoki lebih melakukan pencegahan terhadap serangan Lernaea cyprinacea yang terdapat di kolam dengan menjaga kualitas air serta memilih ikan dengan kualitas yang baik agar serangan Lernaea cyprinacea dapat diminimalisir.

\section{DAFTAR PUSTAKA}

Alifuddin, M., A. Priyono dan A. Nurfatimah. 2002. Inventarisasi Parasit Pada Ikan Hias yang Dilalulintaskan Di Bandara Soekarno-Hatta, Cengkareng, Jakarta. Jurnal Akuakultur Indonesia, 1 (3) : 123-127.

Azwar, S. 2010. Metodologi Penelitian. Pustaka Belajar.

Direktorat Jenderal Perikanan Budidaya. 2012. Segitiga Emas Budidaya Ikan Hias Jawa Timur. www.djpb.kkp.go.id. Diakses pada 24 Mei 2013. 1 hal.

Fidyandini, H.P., S. Subekti dan Kismiyati. 2012. Identifikasi dan Prevalensi Ektoparasit pada Ikan Bandeng (Chanos chanos) yang Dipelihara di Karamba Jaring Apung UPBL Situbondo dan di Tambak Desa Bangunrejo Kecamatan Sidoarjo.
Journal of Marine and Coastal Science, 1(2) : 91 - 112.

Gay, L.R. and Diehl, P.L. 1992. Research Methods for Business and Management. MacMillan Publishing Company, New York.

Kabata, Z. 1979. Parasitic Copepoda of British Fishes. Ray Society London

Kanwal, N., Z. Siraj, Z. Tasawar, F. Mustaq and M.H. Lashari. 2012. The Lernaeid Parasites of Catla Catla. Acta Parasitologica Globalis, 3 (2) : 16-19.

Karantina Ikan Ngurah Rai. 2004. Laporan Pemantauan Hama dan Penyakit Ikan Karantina di Propinsi Bali Tahun Anggaran 2004. Stasiun Karantina Ikan Kelas I Ngurah Rai-Bali. 66 hal.

Kismiyati, G. Mahasri, dan A. Manan. 2011. Buku Ajar Parasit Penyakit Ikan I (Ilmu Penyakit Arthropoda pada Ikan). Fakultas Perikanan dan Kelautan. Universitas Airlangga. Surabaya.

Kismiyati. 2009. Ektoparasit Argulus japonicus (Crustacea: Argulidae) pada Ikan Maskoki Carassius auratus (Cypriniformes: Cyprinidae) dan Upaya Pengendalian dengan ikan Sumatera Puntius tetrazone (Cypriniformes: Cyprinidae). Disertasi. Program Pascasarjana. Universitas Airlangga.

Marina, H., S.J. Beatty, D.L. Morgan, R.G Doupe and A.J. Lymbery. 2008. An Introduce Parasite, Lernaea cyprinacea L., Found on Native Freshwater Fishes in The South West of Western Australia. Journal of The Royal Society of Western Australia 91 : 149-153.

Rukyani, A. dan O. Komaruddin. 1991. Petunjuk Teknis Pengelolaan Kesehatan Ikan Bagi Akuakultur. Pusat Penelitian dan Pengembangan. Bogor.

Shariff, M. and C. Sommerville. 1986. Identification and Distribution of

Diterima/submitted:4 November 2013

Disetujui/accepted:24 Desember 2013 
Lernaea spp. in Penisular Malaysia. The First Asian Fisheries Forum. Asian Fisheries Society, Manila, Philippines. pp 269-272.

Shariff, M. and C. Sommerville. 1986. The Life Cycles of Lernaea polymorpha and Lernaea cyprinacea. The First Asian Fisheries Forum. Asian Fisheries Society, Manila, Philippines. pp 273-278.

Steckler, N and R.P.E. Yanong. 2012. Lernaea (Anchorworm) Infestation in Fish. University of Florida. IFAS Extension. 4 hal.

Syawal, H., Syafriadiman dan S. Hidayah. 2008. Pemberian Ekstrak Kayu Siwak (Salvadora persica L.) untuk Meningkatkan Kekebalan Ikan Mas (Cyprinus carpio L.) yang Dipelihara dalam Keramba. Biodiversitas. Fakultas Perikanan dan Ilmu Kelautan Universitas Riau 1 (9) : 44-47. 